\title{
A Study on Establishment of the Directions of Granting Incentives by Long-life Housing-related Persons
}

\author{
Kim, Eun-young ${ }^{1, a}$, Hwang, Eun-kyoung ${ }^{2, b}$, Woo, Sujin ${ }^{3, c}$ \\ ${ }^{1}$ Dept. of Interior Architecture Design, Hanyang University, South Korea \\ ${ }^{1,3}$ Researcher, Korea Institute of Civil Engineering and Building Technology, South Korea \\ ${ }^{2}$ Research Fellow, Korea Institute of Civil Engineering and Building Technology, South Korea \\ a key@kict.re.kr, bekhwang@kict.re.kr, c sjwoo@kict.re.kr
}

Keywords: Long-Life Housing, Incentive

Abstract. Long-life housing is a type of housing available for about 100 years through replacement of its infills with its supports maintained for a long time. Yet long-life housing is not spread smoothly because of the lack of policies and publicity. In particular, considering the perception that initial construction cost is high, incentive measures need to be established for construction-related persons. Although the current Housing Act provides incentives for relaxing the restrictions on floor-area ratio, building coverage ratio, and building height, their detailed standards are not established. This study intends to derive items for which incentives need to be provided to construction companies, residential property owners, infill manufacturers and designers.

\section{Introduction}

Long-life housing is a type of housing available for about 100 years through replacement of the infills of walls and furniture with its supports such as columns and floors maintained for a long time. In this regard, the government established [Long-life Housing Construction and Certification Standards] dated December 24, 2014. However, as policy measures are not sufficiently established and publicity is not properly made, long-life housing is not preferred much. In particular, considering the perception that the initial construction cost of long-life housing is high, incentive measures need to be established for construction-related persons and residential property owners. Although the current Housing Act provides incentives for relaxing the restrictions on floor-area ratio, building coverage ratio, and building height, their detailed standards are not established. Besides, there are few incentives other than the aforementioned. This study intends to derive items for which incentives need to be provided to construction companies, residential property owners, infill manufacturers and designers. Further, this study also intends to set the direction of providing incentives for the spread of long-life housing.

Interview surveys of and consultations with experts were conducted to set the direction of providing incentives for each person related to long-life housing. Research processes are as follows:

First, the current status of incentives and their redundancy with other systems were reviewed based on the investigation into the relevant laws and regulations and the cases of similar systems.

Second, Interview survey of and consultation with experts were conducted using groups related to long-life housing. Survey was conducted for 20 days ranging from July 1 to July 20, 2015. Related experts were composed of working-level staffs from construction companies, infill manufacturers, a design office and a certification authority. The survey was conducted using individual in-depth interviews and consultation meetings.

Third, main survey contents included the time and method of providing incentives, the prediction of economic impacts and incentive requirements.

\section{Current Status and Problems of Long-life Housing-related Laws and Regulations}

Paragraph 4 of Article 21-6, [Housing Act] stipulates administrative and tax incentives for long-life housing project undertakers and its buyers. Also, Paragraph 7 of Article 21-6, the same Act stipulates 
that the restrictions on building coverage ratio, floor-area ratio and building height can be relaxed within the scope prescribed by Presidential Decree. The restrictions on building coverage ratio and floor-area ratio can be relaxed to maximum $110 \%$, but detailed specifications thereof have yet to be established. Besides, substantial incentives are almost not available for restrictions on building height. Specific measures for administrative and tax incentives are not yet established in Paragraph 4 of Article 21-6, the same Act. The relaxation of construction standards such as the restrictions on building coverage ratio, floor-area ratio and building height is related to incentive items targeting chiefly construction companies, while incentives targeting home owners, infill manufacturers and designers are not diversely established. Table shows the current status of long-life housing-related laws and regulations.

Table 1. Current Status of Long-life Housing-related Laws and Regulations

\begin{tabular}{c|c}
\hline Classification & Contents \\
\hline Article 21-6, Housing Act & $-\begin{array}{c}\text { Administrative and tax incentives for long-life housing project undertakers and } \\
\text { its acquisitor }\end{array}$ \\
$\begin{array}{c}\text { Relaxation of the restrictions on building coverage ratio, floor-area ratio and } \\
\text { building height }\end{array}$ \\
\hline $\begin{array}{c}\text { Article 65-2, Regulations on } \\
\text { Housing Construction } \\
\text { Standard, etc }\end{array}$ & $-\begin{array}{c}\text { Relaxation of the restrictions of floor-area ratio and building coverage ratio by } \\
\text { maximum 110\% of long-life housing under Housing Act }\end{array}$ \\
\hline $\begin{array}{c}\text { Article 22, Rules on } \\
\text { Housing Construction } \\
\text { Standard, etc }\end{array}$ & $-\begin{array}{c}\text { The ratings entitled to relaxation are defined as the ratings above a rating of } \\
\text { Excellence among long-life housing certification ratings under Housing Act. }\end{array}$ \\
\hline
\end{tabular}

\section{Comparison of Incentives of Similar Systems}

The current status of incentives of the related similar systems was reviewed before devising the incentives measures for long-life housing. Green Building Certification Standards, Building Energy Efficiency Rating System and Seoul City District-unit Plan Establishment Standards (2015) include incentive systems similar to Long-life Housing Construction and Certification Standards. Green Building Certification Standards include systems of easing building standards and providing tax credits. Building Energy Efficiency Rating System includes systems of reducing environmental improvement charges and granting bonus points for PQ as well as easing building standards and providing tax credits.

Table 2. Current Status Incentives of Similar Systems

\begin{tabular}{|c|c|c|c|}
\hline Classification & $\begin{array}{c}\text { Green Building Certification } \\
\text { Standards }\end{array}$ & $\begin{array}{c}\text { Building Energy Efficiency } \\
\text { Rating System }\end{array}$ & $\begin{array}{c}\text { Seoul City District-unit Plan } \\
\text { Establishment Standards }\end{array}$ \\
\hline $\begin{array}{l}\text { Relaxation of } \\
\text { building standards }\end{array}$ & $\begin{array}{c}\text { Relaxation of landscaping area } \\
\text { ratio to } 85 \% \text { and floor area } \\
\text { ratio to } 115 \%\end{array}$ & $\begin{array}{c}\text { Relaxation of the restrictions } \\
\text { on floor area ratio, landscaping } \\
\text { area ratio and maximum } \\
\text { building height }\end{array}$ & $\begin{array}{c}\text { Relaxation of the floor-area of } \\
\text { long-life housing by maximum } \\
10 \%\end{array}$ \\
\hline Tax credit & $\begin{array}{l}\text { Reduction in income tax, } \\
\text { corporate income tax, } \\
\text { acquisition tax, } \\
\text { property tax and } \\
\text { registration tax }\end{array}$ & $\begin{array}{c}\text { Reduction of local taxes such } \\
\text { as acquisition tax by } 5 \text { to } 15 \% \\
\text { property tax by } 3 \text { to } 15 \%\end{array}$ & - \\
\hline $\begin{array}{c}\text { Environmental } \\
\text { improvement charge }\end{array}$ & - & $\begin{array}{c}\text { Reduction of environmental } \\
\text { improvement charges by } \\
\text { maximum } 50 \%\end{array}$ & - \\
\hline $\begin{array}{l}\text { Granting bonus } \\
\text { points for } P Q\end{array}$ & - & $\begin{array}{c}\text { Granting bonus points for PQ } \\
\text { such as } 1 \text { point for a top rating } \\
\text { and } 0.5 \text { point for a second } \\
\text { rating }\end{array}$ & - \\
\hline
\end{tabular}


A system of granting bonus points for PQ means the method of granting bonus points to a certified company in pre-qualification screening of eligible bidders. Seoul City District-unit Plan Establishment Standards relax the floor-area ratio of long-life housing by maximum $10 \%$. A related person states that the incentive for floor area ratio is limited to maximum $10 \%$ in consideration of the incentives for floor area ratio of other systems, under the condition that the sum of the incentives for floor area ratio cannot exceed 20\%. Table 3 shows the current status incentives of similar systems.

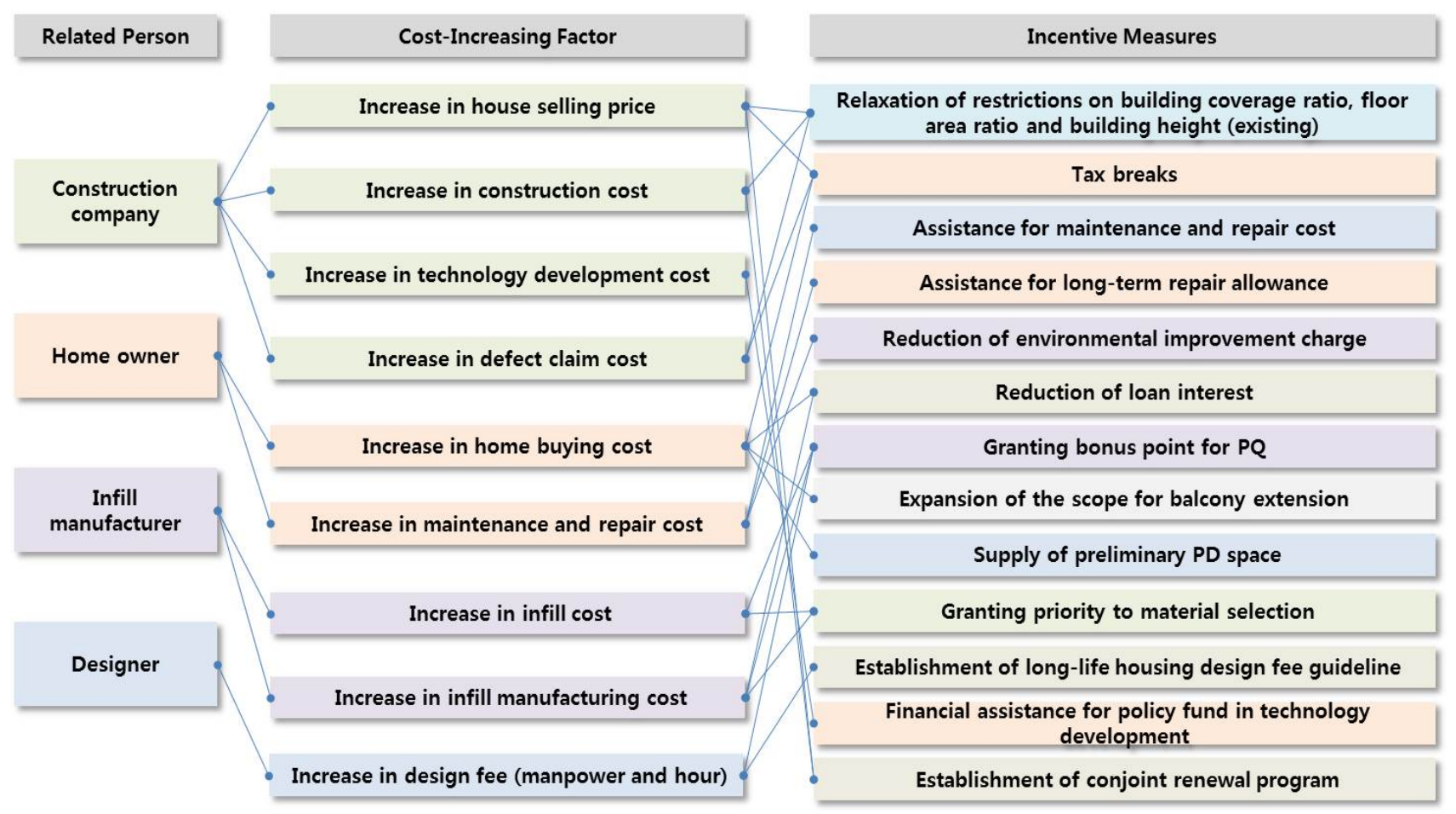

Figure 1. Overall Measures to Improve Incentives by Related Persons

\section{Incentive Measures for Construction Companies}

Satisfactory building coverage ratio and floor-area ratio are currently available to construction companies because incentives have already become available to them by Green Building Certification Standards, etc. Thus the items to which incentives apply are overlapped, which poses a problem in terms of effectiveness. It may be difficult to use building coverage ratio and floor-area ratio according to the type of a project and the location of a site. So, to secure profitability, incentive measures considering the initial construction cost of long-life housing need to be established as follows: a wider range of relaxation of building standards; an enhancement of home buying motivation through supply of housing fitted with a double wide balcony and service area; a system of granting bonus points for PQ in a turnkey project, and a supply of policy fund.

\section{Incentive Measure for Home Owners}

Home owners need an approach in terms of incentives on a level of fund-raising and home maintenance and repairs. Also, like the case of construction companies, incentives such as a double wide balcony and service area will act as favorable items in home owners' deciding on home buying. The results of investigation into other systems shows that it is necessary to work out additional measures to provide financial assistance for home maintenance and repairs and a reduction for local taxes including acquisition tax and property tax. Further, long-life housing should be continuously publicized targeting potential home buyers. 


\section{Incentive Measures for Infill Manufacturers}

As the results of interview survey of infill manufacturers, it is found that the biggest problem is a decrease in opportunities for contractors to use infills due to an increase in construction cost. Thus, it is difficult to activate the infill markets. This difficulty can be fundamentally overcome when the overall long-life housing market becomes expanded with an increase in demand for long-life housing and infill manufacturers' market participation comes to increase naturally with the establishment of incentive measures for infill manufacturers.

An incentive preferred most by infill manufacturers is a system of granting bonus points for PQ and enables them to be selected as excellent product suppliers for government-supplied materials, which expands the opportunity for them to participate in the bidding process of Public Procurement Service.

\section{Incentives Measures for Designers}

As design fee guidelines are not currently established for the designers of long-life housing, it is necessary to work out incentive measures for the additional cost incurred in designing long-life housing. In calculating additional costs, it is necessary to consider manpower and hour required for design. Figure 1 shows the overall measures to improve incentives by related persons.

\section{Summary}

In establishing the incentive measures by related persons, a redundancy with the relevant laws and regulations and other certification systems should be considered in various aspects, not only one certain part. It is necessary to seriously think of and continuously research on the incentives such as tax credits and financial assistance, which need discussions with relevant governmental agencies. Active publicity and education about incentives should be carried out in the expectation that they will improve the recognition of long-life housing.

\section{Acknowledgements}

This study result is a part of the results of research sponsored by Korea Agency for Infrastructure Technology Advancement in 2015. Task number: 15RERP-B082171-02-000000.

\section{References}

[1] Lee B.R., Kim S.A., Hwang E.G., A study on the measures for system improvement to activate long-life housing, Paper collection by Architectural Institute of Korea, Planning (2008), Vol.24 No.3.

[2] Bae B.Y., Problems with incentive system for green consumption and their solutions, KCA Consumer Policy Trends by Korea Consumer Agency (2010), No. 19.

[3] Kim S.A., A report on mid and long-term management strategy according to the lifecycle of collective housing, Korea Institute of Civil Engineering and Building Technology (2013)

[4] Kim S.A., A report on technology development for long-life collective housing with durability and variability, Korea Institute of Civil Engineering and Building Technology (2010)

[5] Kim T.S., System improvement methods to increase energy-efficient housing supply, Korea Housing Association (2015)

[6] Kim H.J., A study on socio-economic effects according to the repeal of setback regulation from road width, Architecture Research Institute of Seoul (2014)

[7] Information on http://law.go.kr 